\title{
Enhancing Soybean Production Through On-Farm Demonstration of Improved Soybean Varieties at Tselemti and Tahtay Adyabo Districts of North-Western Zone Tigray, Ethiopia
}

\author{
Teklemariam Abadi ${ }^{1}$, Desale Gebretsadik ${ }^{1}$, Abadi Girmay ${ }^{1}$, Tesfahun Mekuanint ${ }^{1} \&$ Daniel Desta $^{1}$ \\ ${ }^{1}$ Shire-Maitsebri Agricultural Research Centre, Ethiopia \\ Correspondence: Teklemariam Abadi, Shire-Maitsebri Agricultural Research Centre, P.O.Box 81, Shire- \\ Indaslassie, Ethiopia. E-mail: teklish190@mail.com
}

Received: June 9, 2020 Accepted: July 11, 2020 Online Published: July 28, 2020

\begin{abstract}
Soybean is a drought tolerant crop which can grow from low to medium altitudes. In the lowland areas of NorthWestern Tigray the growing of leguminous crop is very low. To introduce soybean commodity in North-western Tigray, demonstration of improved soybean varieties were conducted in 2018/19. The trail was conducted at Tahtay Adyabo and Tselemti Districts that have a potential for growing the soybean. It was conducted by selecting three Kebelles from the districts. A total of 35 farmers were involved in the intervention. The necessary training was given to the participant farmers and experts. Following this improved seed of Awassa-95 and Gizo varieties at Tahtay Adyabo Districts, and Wegayen and Gizo seed at Tselemti District were offered to participant farmers. Each farmer have been planted a plot size of 0.02 ha for each of the two varieties. The descriptive result shows, Awassa-95 soybean variety has given significantly higher yield at Tahtay Adyabo as compared to Gizo variety. The variety was gave an average yield of $1067 \mathrm{~kg} / \mathrm{ha}$ and $570 \mathrm{~kg} / \mathrm{ha}$ respectively Awassa- 95 and Gizo varieties. On the other hand an average yield of $1231 \mathrm{~kg} / \mathrm{ha}$ and $1052 \mathrm{~kg} / \mathrm{ha}$, respectively was obtained for Gizo and Wegayen varieties at Tselemti District. This shows that Tselemti District is more better for the cropping of Gizo variety. Moreover, the improved soybean verities (Gizo at Tselemti district and Awassa-95 at Tahtay Adyabo district) were found to be early maturing and best option to moisture stressed areas for the society protein source. Based on the result it is recommended to be popularize Awassa-95 soybean variety at Tahtay Adyabo District and Gizao soybean varieties at Tselemti District to large farmers. Therefore, the research center and the office of agriculture and rural development of the Districts to be popularized the varieties to large number farmers of the areas.
\end{abstract}

Keywords: demonstration, farmers perception, soybean

\section{Introduction}

Soybean (Glycine max) is one of the most important food plants of the world. This crop is tolerant to moisture stress which grows in the altitude ranged from 0-2200 m above sea level (Urgessa, 2015). Moreover, soybean is the main source of edible oil globally with the highest gross output of vegetable oil among the cultivated crops with total cultivated area of 121.5 million ha and total production of 334.8 million tons with the productivity of 2.76 ton ha ${ }^{-1}$ (Dragan et al., 2016). Soybean is a stable food of great nutritional value. It is an important global crop providing oil and protein. Soybean plant has tawny or grey-color pubescence on the stems, leaves and pods and also the presence of rhizobium japonicum on the roots to fix atmospheric nitrogen.

Considering many advantages of the crop, soybean was introduced to Ethiopia in the early 1950s. Though its introduction to the country it has become one of the most important lowland grain legumes in the country by adapting to diverse agro ecological zones. As soybean provides a nutritious combination of calorie and protein intake, producing and consuming more soybean would improve food insecurity and malnutrition of the society (Hailegiorgis, 2010).

Even though soybean can be grown in different parts of the country, the major areas currently growing are in the Western and South-Western part of the country, notably Benishangul-Gumuz, Gambela and parts of Oromia Region and, to a lesser extent, in the Amhara Region.

In recent years given the wide range of health and other diverse benefits of soybean; the country started exporting the crop. Production and area cultivated under soybean in the country has also shown an increased trend. For instance in area coverage it increased from 26,000 ha in $2013 / 14$ to 38,072 ha in $2017 / 18$ and in production it 
raised from 49,000 ton in $2013 / 14$ to $86,467.8$ ton in $2017 / 18$. Though Tigray Region has potential areas for growing soybean but cultivation of this crop is negligible and not yet included in the crop type produced in the region as reported by (CSA, 2018). So to introduce the crop to North-Western Tigray, Shire-Maitsebri Agricultural Research Center is conducting many research activities. Therefore Shire-Maitsebri Agricultural Research Center recommended three varieties namely, Gizo, Awassa-95 and Wegyen soybean varieties to be demonstrated at the farmers field. Thus, this study was aimed to enhance soybean production and create awareness on the improved soybean varieties to the farming community.

\section{Research Methodology}

\subsection{Description of the Study Area}

The study was conducted at Tahtay Adyabo and Tselemti Districts of North-Western zone of Tigray, Ethiopia. Tahtay Adyabo is located at the degree of 14.05-14.89 ${ }^{\circ} \mathrm{C}$ Northing and 37.34-38.17 ${ }^{\circ} \mathrm{C}$ Easting. The District has $38-40^{\circ} \mathrm{C}$ of temperature and $450 \mathrm{~mm}-550 \mathrm{~mm}$ annual rainfall. Agro ecologically $94.13 \%$ of the District is lowland and the remaining 5.87\% is midland. Likewise, Tselemti District is located in the altitude ranges from 800-2870 meter above sea level, and latitude and longitude of $13^{\circ} 05^{\prime} \mathrm{N}$ and $38^{\circ} 08^{\prime} \mathrm{E}$, respectively. The mean maximum and minimum temperature are $38{ }^{\circ} \mathrm{Cand} 16^{\circ} \mathrm{C}$ respectively and the area receives annual rainfall of $758-1100 \mathrm{~mm}$. Agro ecologically $78.35 \%, 19 \%$ and $2.65 \%$ of the District is lowland, midland and highland, respectively (OoARD of the hosted Districts, 2016). Demonstration of the improved soybean variety was conducted at lowland parts of the Districts in 2018 by purposively selecting according their potentials for growing the crop. Three potential for growing soybean Kebelles namely; Lemlem, Medhanalem and Wuhdet Kebelles was selected for conducting the demonstration trail. A total of 35 farmers were participated in executing of the trail. Training was given to farmers, DAs and experts. Improved seed of Wegayen and Gizo soybean varieties in Tselemti and, seed of Gizo and Awasa95 soybean varieties in Tahtay Adyabo District were delivered to the farmers. Each farmer has planted a plot size of 0.02 ha for each of the two varieties. Experience sharing was held at maturity stage of the crop by including farmers, Development Agents, Experts and researchers.

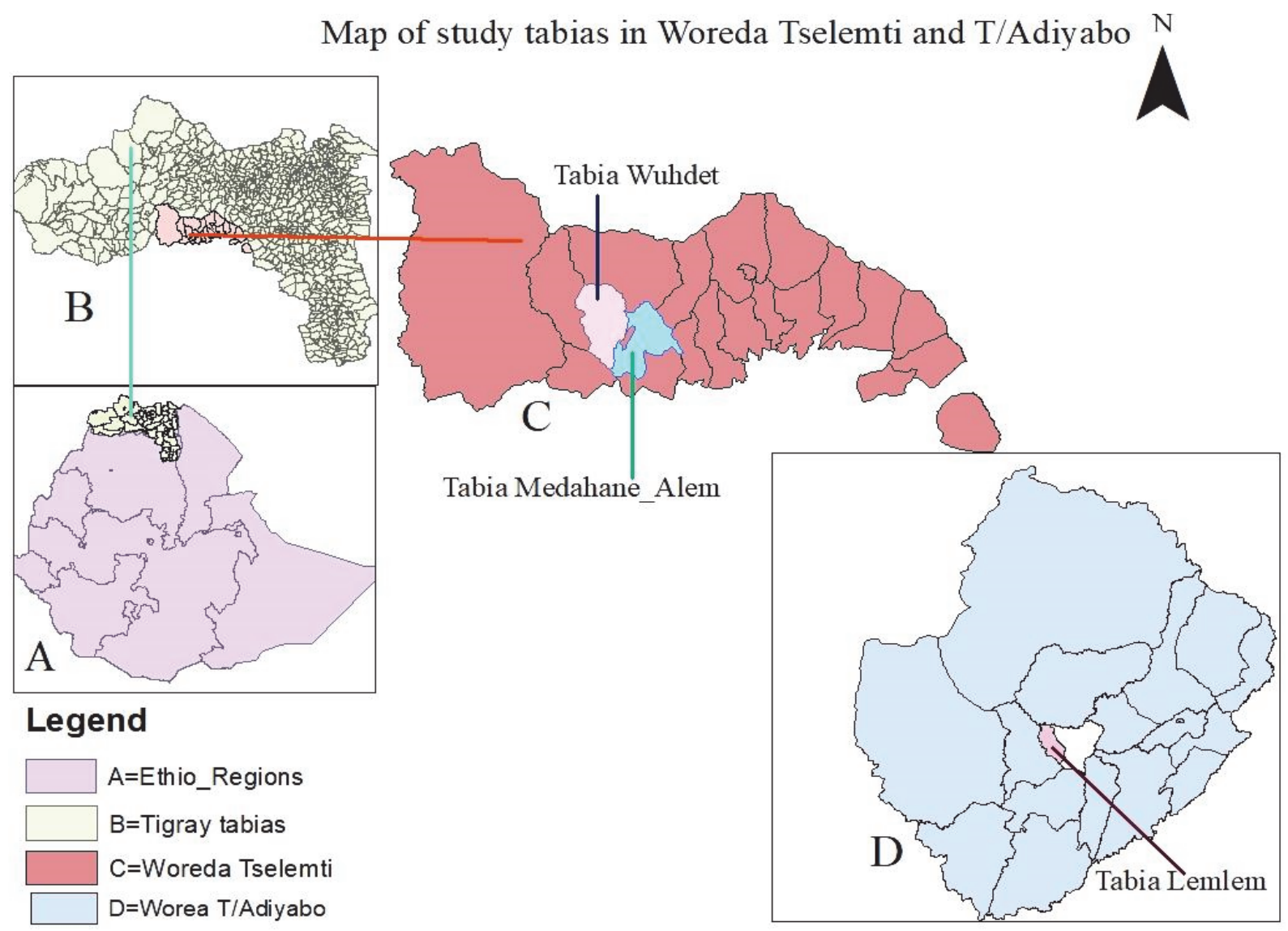

Figure 1. Map of the study area 


\subsection{Data Collection and Analysis}

Quantitatively data on grain yield was collected from the farmers field using a quadrant. Whereas for the qualitative data, farmers' perception have been collected from 18 farmers on different attributes of the commodity. The response of the farmers on the demonstrated of improved soybean varieties was collected from 18 randomly selected farmers. Attributes such as germination performance, higher number of capsule, early maturity, drought tolerance, diseases tolerance, insect tolerance, its taste, seed weight and grain yield was used to compare the improved soybean varieties for the specified commodity attributes. Five levels strongly disagree, disagree, no change, agree and strongly agree was used to compare the attributes for the varieties. The scale for levels is given starting from 1-5 respectively for the mentioned levels. The collected data was analyzed using descriptive statistics such as mean, Std.Dev and percent.

\section{Result and Discussions}

\subsection{Grain Yield}

Table 1. Yield obtained from improved soybean varieties $(\mathrm{n}=9)$

\begin{tabular}{lllllllll}
\hline SN & District & Variety & $\begin{array}{l}\text { Min } \\
(\mathrm{kg} / \mathrm{ha})\end{array}$ & $\begin{array}{l}\text { Max } \\
(\mathrm{kg} / \mathrm{ha})\end{array}$ & $\begin{array}{l}\text { Mean } \\
(\mathrm{kg} / \mathrm{ha})\end{array}$ & Std.Dev. & P-va lue & $\begin{array}{l}\text { Yield increment } \\
\text { in }(\%)\end{array}$ \\
\hline 1 & Tselemti & Wegayen & 520 & 1381 & 1052 & 3.953 & 0.489 & 17.01 \\
& & Gizo & 633 & 1650 & 1231 & 3.879 & & \\
2 & T/Adyabo & Gizo & 378 & 710 & 570 & 1.460 & 0.004 & 87.19 \\
& & Awassa- & 820 & 1200 & 1067 & 1.692 & & \\
& 95 & & & & & & \\
\hline
\end{tabular}

Gizo variety gave better yield as compared to Wegayen at Tselemti District, which is $17.01 \%$ yield increment. On the other side in Tahtay Adyabo District Awassa-95, gave significantly higher yield than Gizo soybean variety which is $87.19 \%$ yield increment. Though the productivity of the soybean obtained in the area is below the national average which is $2270 \mathrm{~kg} / \mathrm{ha}$, but the yield gained in the area is promising result (CSA, 2018).
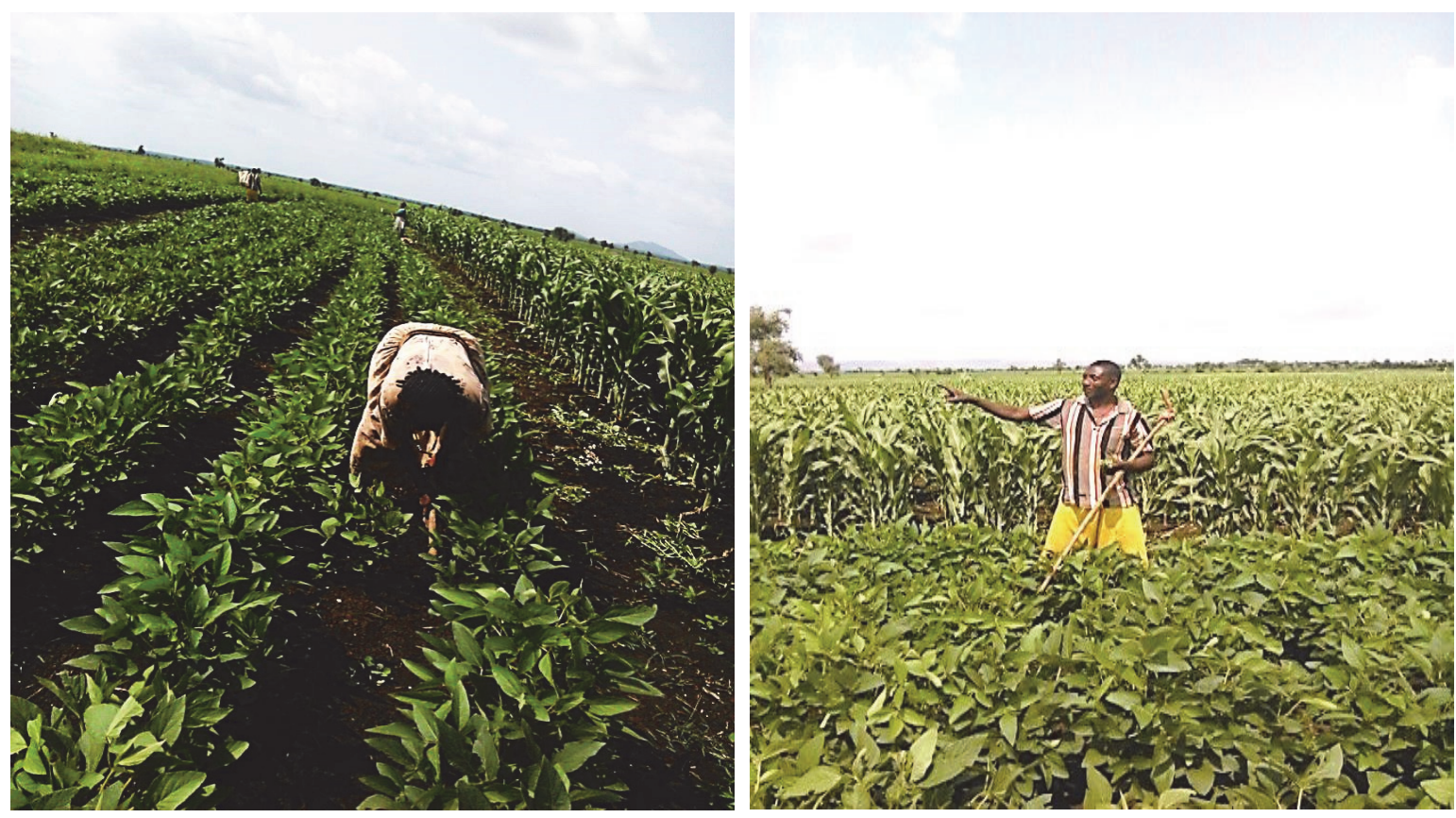

Figure 2. Farmers conducted managemental practices on the demonstrated improved soybean varieties (Ms Shwaynesh Redda and Mr Gebru Redda) at Tahtay Adyabo district, August 2018 

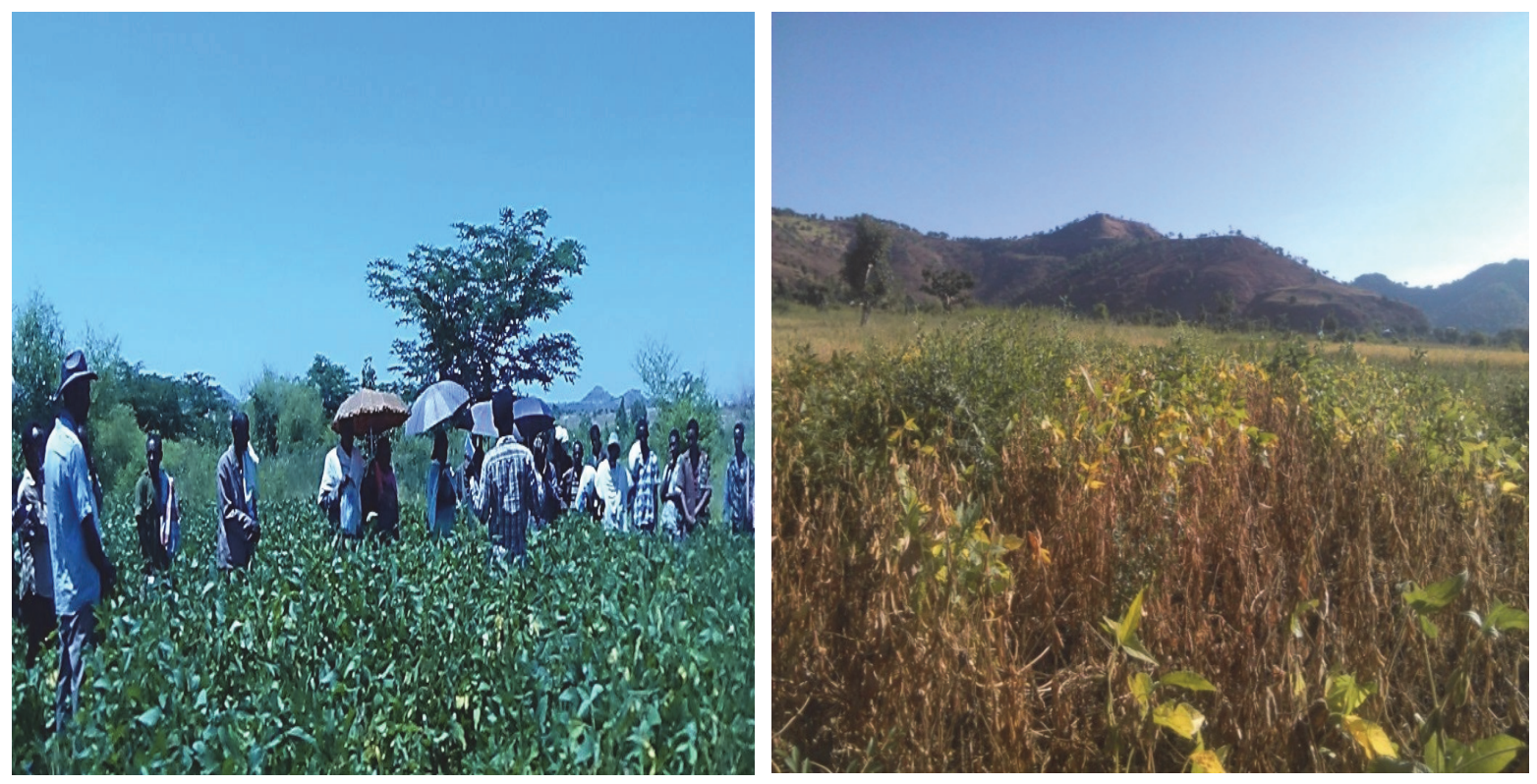

Figure 4. Farmers field day on the demonstrated soybean varieties, September 2018

\subsection{Farmers Preference}

As indicated in table 2 farmers were preferred Awassa- 95 soybean variety in attributes such as early maturity, drought tolerance, capsule number and its yield as compared to Gizo variety. In general base the farmers are agreeing as Awassa-95 soybean variety is preferred on the main attributes of the commodity as compared to Gizo variety at Tahtay Adyabo District. On the other hand farmers agreed that Gizo variety were better in its earliness, capsule number and its yield as compared to Wegayen variety at Tselemti District. Generally, farmers had preferred Awassa-95 and Gizo as better performing variety with the overall mean score of 4.55 and 4.44 respectively at Tahtay Adyabo and Tselemti District (Table2).

Table 2. Farmers' response on attributes of soybean, Awassa-95 versus Gizo soybean variety at Tahtay Adyabo District and Gizo versus Wegayen variety at Tselemti District.

\begin{tabular}{llllll}
\hline \multirow{2}{*}{ SN } & \multirow{2}{*}{ Attributes } & \multicolumn{2}{c}{ At Tahtay Adyabo District } & \multicolumn{2}{c}{ At Tselemti District } \\
\cline { 3 - 6 } & & \multicolumn{2}{c}{ N (8) $(10)$} & \\
\cline { 3 - 6 } & & \multicolumn{2}{c}{ Variety } & \multicolumn{2}{c}{ Gariety } \\
\cline { 3 - 6 } & Gizo & Awassa-95 & Wegayen \\
\cline { 3 - 6 } 1 & Germination performance & 5 & 5 & 5 & 5 \\
2 & Early maturity & 2 & 5 & 2 & 2 \\
3 & Capsule number & 2 & 5 & 4 & 3 \\
4 & Drought tolerance & 2 & 5 & 5 & 4 \\
5 & Diseases tolerance & 3 & 4 & 5 & 3 \\
6 & Insects tolerance & 3 & 4 & 5 & 2 \\
7 & Its taste in stew or other forms & 4 & 4 & 5 & 4 \\
8 & Seed weight & 4 & 4 & 4 & 4 \\
9 & Grain yield & 3 & 5 & 5 & 3 \\
& Total score & $\mathbf{2 8}$ & $\mathbf{4 1}$ & $\mathbf{4 0}$ & $\mathbf{3 0}$ \\
& Mean & $\mathbf{3 . 1 1}$ & $\mathbf{4 . 5 5}$ & $\mathbf{4 . 4 4}$ & $\mathbf{3 . 3 3}$ \\
\hline
\end{tabular}

\section{Conclusion and Recommendations}

Demonstration trail of improved soybean varieties was conducted at Tselemti and Tahtay Adyabo Districts. On average basis, Gizo variety gave higher yield as compared to Wegayen soybean variety at Tselemti District. But at Tahtay Adyabo District, Awassa-95 was gave better yield than Gizo variety. Therefore, the improved variety, 
Gizo soybean variety, at Tselemti District and Awassa-95 soybean variety at Tahtay Adyabo District has to be popularized to large farmers of the area so as to enhance the leguminous crop production in the area.

\section{Acknowledgement}

The authors would like to acknowledge Agricultural Growth Programme for the research grant. Special thanks also go to agricultural experts and respondent farmers of the hosted Districts for their kind cooperation in conducting the study.

\section{References}

CSA (Central Statistics Agency). (2014). Area and production of Major crops, Addis Ababa, Ethiopia.

CSA (Central Statistics Agency). (2018). Area and production of Major crops, Addis Ababa, Ethiopia.

Dragan, T., Vera, P., Mladen, T., Viliana, V., Vera, D., ... Pasaga, A. (2016). Soybean Area, Yield and Production in World. Xxii Eco-Conference. 2018. Ecological Movement of Novi Sad. Retrieved from https://www.researchgate.net/publication/327982246

Hailegiorgis, B. A. (2011). Export Performance of Oilseeds and ITS Determinants in Ethiopia. American Journal of Economics, 1(1), 1-14. https://doi.org/10.5923/j.economics.20110101.01

OoARD (Office of Agriculture and Rural Development). (2016). Unpublished report of the hosted Districts.

Urgessa, T. (2015). Empirical Review of Production, Productivity and Marketability of Soya Bean in Ethiopia. International Journal of u-and e-Service, Science and Technology, 8(1), 61-66. https://doi.org/10.14257/ijunesst.2015.8.1.06

\section{Copyrights}

Copyright for this article is retained by the author(s), with first publication rights granted to the journal.

This is an open-access article distributed under the terms and conditions of the Creative Commons Attribution license (http://creativecommons.org/licenses/by/4.0/). 